\title{
PENINGKATAN HASIL BELAJAR MATEMATIKA MELALUI MODEL PEMBELAJARAN DISCOVERY LEARNING BERBANTUAN MEDIA GAMBAR PADA SISWA KELAS 4 SDN CUKIL 01 KABUPATEN SEMARANG SEMESTER II
}

\author{
Balad Ikklima', Wasitohadi², Theresia Sri Rahayu ${ }^{3}$ \\ 1Pendidikan Guru Sekolah Dasar, Universitas Kristen Satya Wacana, 292014097@student.uksw.edu \\ 2Pendidikan Guru Sekolah Dasar, Universitas Kristen Satya Wacana, wasitohadi@staff.uksw.edu \\ 3Pendidikan Guru Sekolah Dasar, Universitas Kristen Satya Wacana, th.rahayu@gmail.com
}

\section{INFO ARTIKEL}

Riwayat Artikel:

Diterima: $27-03-2018$

Disetujui: 10-04-2018

\section{Kata Kunci:}

Discovery Learning Hasil Belajar

\begin{abstract}
ABSTRAK
Abstrak: Penelitian ini merupakan penelitian tindakan kelas (PTK). Hasil penelitian adalah bahwa penerapan model $D L$ dapat meningkatkan hasil belajar matematika pada materi perkalian dan pembagian pecahan. Pada kondisi awal, siswa yang tuntas berjumlah 8 siswa dengan persentase $27 \%$. Pada pelaksanaan siklus I, siswa yang mencapai nilai di atas KKM mengalami peningkatan menjadi 19 siswa dengan persentase 65\%. Pada siklus II, jumlah siswa yang tuntas mengalami peningkatan menjadi 24 siswa dengan persentase $82 \%$.
\end{abstract}

\begin{abstract}
This study is a classroom action research (PTK). The result of the research is that application of $D L$ model can improve mathematics learning result in multiplication material and fractional division. In the initial conditions, students who complete the total of 8 students with a percentage of $27 \%$. In the implementation of cycle I, students who achieve the above scores KKM increased to 19 students with a percentage of $65 \%$. In cycle II, the total number of completed students increased to 24 students with $82 \%$ percentage.
\end{abstract}

\section{A. LATAR BELAKANG}

Pembukaan Undang-Undang Dasar 1945 alinea 4 menyebutkan bahwa salah satu cita-cita bangsa Indonesia adalah mencerdaskan kehidupan bangsa. Artinya, Indonesia memiliki cita-cita untuk menjadi negara yang memiliki Sumber Daya Manusia yang cerdas. Hal itu dapat dicapai salah satunya melalui pendidikan.

Pendidikan tidak bisa dilepaskan dari proses pembelajaran di kelas. Proses pembelajaran pada jenjang pendidikan dasar merupakan salah satu faktor yang dapat mempengaruhi keberhasilan suatu pendidikan pada jenjang selanjutnya. Proses pembelajaran telah diatur dalam Permendiknas No. 14 tahun 2008 tentang Standar Proses untuk Satuan Pendidikan Dasar dan Menengah. Peraturan tersebut menyebutkan bahwa guru hendaknya menciptakan proses pembelajaran yang interaktif, inspiratif, menyenangkan, menantang, dan memotivasi peserta didik untuk berpartisipasi aktif, serta memberikan ruang yang cukup bagi prakarsa, kreativitas, dan kemandirian sesuai dengan bakat, minat, dan perkembangan fisik serta psikologis peserta didik.

Standar ini juga harus digunakan termasuk dalam melaksanakan pembelajaran matematika.

Standar isi pembelajaran matematika telah diatur dalam PP No. 19 Tahun 2010 tentang Standar Nasional
Pendidikan. Peraturan tersebut menyebutkan bahwa mata pelajaran matematika pada SD/MI/Paket A atau bentuk lainnya yang sederajat dimaksudkan untuk mengenal, menyikapi, dan mengapresiasi ilmu pengetahuan dan teknologi, serta menanamkan kebiasaan berpikir dan berperilaku ilmiah yang kritis, kreatif dan inovatif. Namun tidak semua pembelajaran matematika telah memenuhi standar proses dan standar isi tersebut. Salah satu diantaranya terjadi dalam pembelajaran matematika pada siswa kelas IV SD Negeri Cukil 01.

Hasil observasi dalam pembelajaran matematika siswa kelas IV di SDN Cukil o1 yang dilakukan peneliti menunjukkan bahwa proses pembelajaran matematika di kelas belum berjalan interaktif, inspiratif dan juga belum memberikan kesempatan siswa untuk berpartisipasi secara aktif. Siswa terlihat kurang antusias dalam mengikuti pembelajaran karena kurangnya media / alat peraga sebagai penunjang pembelajaran sehingga siswa kurang tertarik dan terlihat bosan ketika pembelajaran berlangsung. Proses pembelajaran yang tidak berfokus pada siswa namun justru guru yang mendominasi pelaksanaan proses belajar. Hal itu dapat dilihat dari bagaimana guru langsung memberikan dan menjelaskan materi, siswa hanya duduk dan mendengar untuk menerima materi. 
Proses pembelajaran matematika yang terjadi di kelas tersebut adalah proses tranfer (perpindahan) pengetahuan/informasi dari guru ke siswa tanpa adanya upaya guru untuk menggali pengetahuan yang dimiliki siswa guna mempelajari konsep baru.

Proses pembelajaran yang terjadi selanjutnya adalah pemberian contoh soal dari penerapan konsep yang diberikan. Seperti halnya dalam mempelajari konsep, pada tahap ini pun guru masih merupakan pihak yang paling mendominasi. Hal ini dapat dilihat bagaimana guru sebagai pihak yang mengajukan pertanyaan dan guru pula yang menyelesaikan soal tersebut. Peran siswa dalam pembelajaran matematika hanya terlihat dari proses soal latihan, itu pun terbatas. Siswa hanya menyelesaikan soal yang sesuai dengan contoh dan jika ada variasi soal lainnya, maka kembali guru yang harus menyelesaikannya untuk memberikan contoh.

Hasil belajar dari proses pra siklus pembelajaran matematika di SDN Cukil o1 kelas IV tersebut tidak optimal. Berdasarkan data dari daftar nilai guru terlihat dari KKM yang ditentukan $\geq 70$, dari 29 siswa hanya 8 siswa yang tuntas dengan persentase $27 \%$, dan yang tidak tuntas sebanyak 21 siswa dengan persentase $73 \%$. Rata-rata matematika yang dicapai 29 siswa kelas IV hanya sebesar 56,06 dengan nilai minimum 36 dan nilai maksimum 83 . Oleh karena itu perlu adanya upaya tindak lanjut dari permasalahan yang terjadi dalam pembelajaran matematika siswa kelas IV di SD Negeri Cukil 01.

Terdapat beberapa faktor yang mempengaruhi hasil belajar, menurut Wasliman (2009:158) hasil belajar yang dicapai oleh peserta didik adalah hasil interaksi dari berbagai faktor, baik faktor internal maupun eksternal. Faktor Internal merupakan faktor yang bersumber dari dalam diri peserta didik, yang mempengaruhi kemampuan belajarnya. Faktor internal ini meliputi: kecerdasan, kebiasaan belajar, motivasi belajar, ketekunan, minat dan perhatian, sikap, serta kondisi fisik dan kesehatan.

Faktor Eksternal merupakan faktor yang berasal dari luar diri peserta didik yang mempengaruhi hasil belajar yaitu keluarga, sekolah, dan masyarakat. Oleh karena itu dipilihlah salah satu faktor eksternal yaitu penerapan model pembelajaran guna meningkatkan hasil belajar. Model pembelajaran yang dipilih adalahmodel pembelajaran yang sesuai dengan standar proses dan standar isi, namun juga memperhatikan hakikat belajar matematika, dengan tidak menegsampingkan karakteristik siswa.

Belajar menurut paham ini adalah bagaimana siswa mengkonstruksikan suatu konsep berdasarkan pengetahuan yang dimiliki sebelumnya dan peran guru hanya sebagai fasilitator untuk membantu siswa dalam menciptakan iklim belajar yang kondusif (Heruman, 2013:5). Dari segi karakteristik siswa, siswa SD kelas IV berusia 9-11 tahun. Menurut teori Piaget (Schunk, 2012:333), siswa dengan usia ini masuk dalam kategori tahap operasional konkrit. Artinya, siswa pada tahap ini harus belajar dengan diarahkan pada hal yang bersifat konkrit. Pada tahap ini siswa sudah dapat melakukan pemecahan masalah yang agak komplek selama masalah itu konkrit dan tidak abstrak.

Menurut Bruner (Heruman, 2013:4), belajar matematika tidak lepas dari belajar konsep. Dalam matematika, setiap konsep berkaitan dengan konsep lain, dan suatu konsep menjadi prasyarat bagi konsep yang lain. Oleh karena itu, siswa harus lebih banyak diberi kesempatan untuk melakukan keterkaitan tersebut. Dalam belajar, siswa tidak menerima, tetapi mengkonstruk sendiri konsep-konsep yang dipelajari. Oleh karena itu diperlukan model pembelajaran yang memberi kesempatan siswa untuk mengkonstruk sendiri bukan sekedar menerima pembelajaran itu. Salah satu model pembelajaran yang menekankan konsep tersebut adalah model pembelajaran Discovery Learning (DL).

Discover berarti menemukan, sedangkan Discovery adalah penemuan. Oleh karena itu, Illahi (2012: 33-34) mendefinisikan $D L$ sebagai salah satu model yang memungkinkan para anak didik terlibat langsung dalam kegiatan belajar mengajar, sehingga mampu menggunakan proses mentalnya untuk menemukan suatu konsep atau teori yang sedang dipelajari. Menurut Wilcox (Hosnan, 2014: 281), pembelajaran $D L$ mendorong siswa untuk belajar sebagian besar melalui keterlibatan aktif mereka sendiri dengan konsep-konsep dan prinsip-prinsip, dan guru mendorong siswa untuk memiliki pengalaman dan melakukan percobaan yang memungkinkan mereka menemukan prinsip-prinsip untuk diri mereka sendiri.

Berdasarkan permasalahan yang terjadi dalam pembelajaran matematika siswa kelas IV SDN Cukil 01, maka dilakukan penelitian dalam upaya memperbaiki proses pembelajaran guna meningkatkan hasil belajar. Berdasarkan model Discovery Learning, maka peneliti menggunakan penelitian yang berjudul "Peningkatan Hasil Belajar Matematika Melalui Model Pembelajaran Discovery Learning Berbantuan Media Gambar Pada Siswa Kelas 4 SDN Cukil o1 Kecamatan Tengaran Kabupaten Semarang Semester II Tahun Pelajaran 2017/2018".

\section{B. METODE PENELITIAN}

Jenis Penelitian yang dilaksanakan dalam penelitian ini adalah Penelitian Tindakan Kelas (PTK) atau Classroom Action Research (CAR). Penelitian Tindakan Kelas (PTK) merupakan suatu bentuk tindakan refleksi diri yang dilakukan dengan penyelidikan sistematis oleh guru atau orang lain yang 
bertujuan untuk memecahkan masalah nyata yang berfokus pada suatu kelas.

Adapun lokasi yang dipilih dalam melaksanakan penelitian adalah di SD Negeri Cukil o1. Lokasi SD N Cukil o1 terletak di Desa Cukil Kecamatan Tengaran Kabupaten Semarang. Penelitian ini hanya dilakukan di kelas IV yang siswanya terdiri dari 29 siswa diantaranya 15 siswa laki-laki dan 14 siswa perempuan. Penelitian dilakukan pada semester II, tahun ajaran 2017/2018 di SD Negeri Cukil 01. Penelitian siklus I dilaksanakan sebanyak 3 kali pertemuan, setiap pertemuan 2 x 35 menit tatap muka. Untuk pertemuan ketiga, dilakukan evaluasi. Penelitian dimulai pada Minggu kedua bulan Maret sampai minggu ketiga bulan Maret.

Penelitian ini dilakukan dalam dua siklus. Setiap siklus terdiri dari tiga kali pertemuan. Pelaksanaan siklus I telah direncanakan dengan sebaik-baiknya, agar dalam pelaksanaannya dapat berjalan dengan lancar dan sistematis. Pelaksanaan siklus I terlaksana sesuai dengan jadwal yang sudah dibuat dalam tabel 1, dilaksanakan tiga kali pertemuan di setiap siklusnya dengan waktu dua jam pelajaran (2 x 35 menit) dan indikator yang berbeda untuk setiap pertemuannya. Siklus I dilaksanakan melalui empat tahap yaitu: tahap perencanaan, tahap pelaksanaan, observasi, dan refleksi.

Siklus II dilaksanakan berdasarkan perbaikanperbaikan menurut hasil refleksi siklus I. Siklus II dilaksanakan dengan tiga kali pertemuan dan KD yang berbeda dari siklus I serta indikator yang berbeda-beda untuk setiap pertemuannya yaitu pertemuan pertama dan pertemuan kedua. Sedangkan pertemuan ketiga kegiatam pembelajaran hanya mengulas materi yang telah dipelajari pada pertemuan pertama dan kedua pada siklus II dan mengerjakan soal evaluasi. Pelaksanaan siklus II melalui beberapa tahap yaitu tahap perencanaan, pelaksanaan, observasi dan refleksi.

Apabila pembelajaran pada siklus II terjadi peningkatan dalam hasil belajar pada pembelajaran matematika dari nilai KKM $\geq 70$ atau dengan persentase klasikal 80\% dari 29 siswa, maka tidak perlu diadakan perbaikan kembali dan penerapan model discovery learning berbantuan media gambar pada pembelajaran matematika dinyatakan berhasil.

Pada penelitian ini, peneliti menggunakan tes tertulis sebagai alat pengumpulan data hasil belajar siswa kelas 4 pembelajaran matematika, dalam mengamati proses pembelajaran peneliti menggunakan lembar observasi. Pada penelitian ini, peneliti akan menggunakan uji validitas dan reliabilitas untuk mengetahui jumlah soal yang valid. Hasil belajar matematika dianalisis menggunakan teknik analisis deskriptif komparatif untuk membandingkan hasil belajar setelah tindakan siklus I dan siklus II.

\section{HASIL DAN PEMBAHASAN}

\section{Deskripsi Pra Siklus}

Pra siklus dilaksanakan pada tanggal 26 Februari 2018 dengan mengobservasi KBM yang berlangsung pada mata pelajaran matematika kelas IV SDN Cukil o1. Peneliti melakukan observasi dari jam pertama sampai jam ketiga yaitu pukul 07.00-08.45 WIB, sedangkan wawancara dengan guru kelas IV dilakukan pada saat istirahat pertama. Pada saat pembelajaran, terlihat siswa tidak semangat dalam mengikuti pembelajaran dan banyak siswa yang asyik mengobrol dengan temannya.

Dari hasil wawancara diperoleh hasil belajar matematika siswa kelas IV rendah. Dapat dilihat dari hasil evaluasi matematika dengan KKM 70 hanya 8 siswa yang tuntas (dapat dilihat dalam tabel 14) dari 29 siswa. Alasan masih banyak siswa yang tidak tuntas salah satunya adalah kurang ketelitian antara bilangan positif dan negatif serta kurang memahami soal.

TABEL 1

KETUNTASAN HASIL BELAJAR MATEMATIKA SISWA KELAS 4 SDN CUKIL O1 SEMESTER II TAHUN PELAJARAN 2017/2018 PRA SIKLUS

\begin{tabular}{|l|l|c|l|}
\hline 1 & Tuntas & 8 & $27 \%$ \\
\hline 2 & Tidak Tuntas & 21 & $73 \%$ \\
\hline 3 & Jumlah & 29 & $100 \%$ \\
\hline 4 & Nilai rata-rata & \multicolumn{2}{|c|}{56,06} \\
\hline 5 & Nilai Minimal & \multicolumn{2}{|c|}{36} \\
\hline 6 & Nilai Maksimal & \multicolumn{2}{|c|}{83} \\
\hline
\end{tabular}

Tabel 1 menunjukkan bahwa hasil belajar matematika siswa kelas 4 SDN Cukil o1 semester II tahun pelajaran 2017/2018 mempunyai nilai rata-rata kelas 56,06 dengan nilai minimal 36 dan nilai maksimal 83. Siswa yang telah mencapai $\mathrm{KKM} \geq 70$ berjumlah 8 siswa sedangkan yang kurang dari KKM < 70 berjumlah 21 siswa.

\section{Deskripsi Siklus I}

Pelaksanaan siklus I dilaksanakan dengan tiga kali pertemuan yang berlangsung pada tanggal 19,21,22 Maret 2018. Pertemuan pertama dilaksanakan pada tanggal 19 Maret 2018 pukul 07.00-08.10 WIB. Materi pada pertemuan pertama tentang apa itu pecahan, macam-macam perkalian pecahan (perkalian pecahan biasa, perkalian bilangan bulat dengan pecahan campuran). Kegiatan pembelajaran terdiri dari kegiatan awal, kegiatan inti, dan penutup.

Hasil observasi kegiatan mengajar guru siklus I yang dilakukan oleh observer pada peneliti kelas 4 pelajaran matematika saat mengajar menggunakan model pembelajaran discovery learning dapat dilihat pada tabel 2. 
TABEL 2

HASIL OBSERVASI MENGAJAR GURU SIKLUS I

\begin{tabular}{|c|l|c|c|}
\hline No & \multicolumn{1}{|c|}{$\begin{array}{c}\text { Indikator } \\
\text { Penilaian }\end{array}$} & $\begin{array}{c}\text { Nomor Item } \\
\text { yang Dilakukan } \\
\text { Guru }\end{array}$ & $\begin{array}{c}\text { Ju } \\
\mathbf{m l} \\
\mathbf{a h}\end{array}$ \\
\hline 1 & $\begin{array}{l}\text { Indikator kegiatan } \\
\text { mengajar yang } \\
\text { dilakukan oleh guru. }\end{array}$ & $\begin{array}{c}2,3,4,5,6,7,8,9,10,1 \\
1,12,15,16,17,18 \\
, 20,21,22,23,24\end{array}$ & 20 \\
\hline 2 & $\begin{array}{l}\text { Indikator kegiatan } \\
\text { mengajar yang tidak } \\
\text { dilakukan oleh guru. }\end{array}$ & $1,6,14,19$ & 3 \\
\hline
\end{tabular}

Berdasarkan tabel 5 ada 20 indikator penilaian kegiatan mengajar yang sudah dilaksanakan oleh guru sesuai dengan lembar observasi mengajar guru dan masih ada 4 indikator yang belum dilakukan oleh guru yaitu tidak mempersiapkan ruang kelas yang akan digunakan untuk proses pembelajaran, tidak memeriksa kesiapan siswa saat akan mengikuti pembelajaran dan tidak meluruskan kesalahan pemahaman siswa terhadap materi. Sebenarnya guru sudah melaksanakan pembelajaran dengan mengunakan model pembelajaran discovery learning cukup baik, hal ini terbukti hampir semua indikator penilaian kegiatan mengajar guru sudah dilaksanakan.

Berdasarkan data hasil belajar matematika siklus I dengan membandingkan KKM matematika yaitu $\geq 70$, diperoleh hasil bahwa masih ada siswa yang belum mencapai KKM. Berikut disajikan tabel analisis ketuntasan hasil belajar matematika siklus I siswa kelas 4 SD Negeri Cukil o1 Semester II/2017-2018.

TABEL 3

ANALISIS KETUNTASAN HASIL BELAJAR MATEMATIKA SIKLUS I SISWA KELAS 4 SD NEGERI CUKIL 01 SEMESTER II/2017-2018

\begin{tabular}{|l|l|l|l|}
\hline No & \multicolumn{1}{|c|}{ Ketuntasan } & f & \% \\
\hline 1 & Tuntas & 19 & $65 \%$ \\
\hline 2 & Tidak Tuntas & 10 & $35 \%$ \\
\hline & Rata-rata & \multicolumn{2}{|c|}{65,47} \\
\hline & Nilai Maksimum & \multicolumn{2}{|c|}{100} \\
\hline & Nilai Minimum & \multicolumn{2}{|c|}{30} \\
\hline
\end{tabular}

Berdasarkan tabel 8 terlihat bahwa siswa yang mencapai batas KKM yaitu $\geq 70$ berjumlah 19 siswa dengan persentase $65 \%$ dan yang belum mencapai KKM yaitu $<70$ berjumlah 10 siswa dengan persentase $35 \%$. Memiliki rata-rata kelas 65,47 dengan nilai minimum 30, dan nilai maksimum 100.

\section{Deskripsi Siklus II}

Siklus II dilaksanakan berdasarkan perbaikanperbaikan menurut hasil refleksi siklus I. Siklus II dilaksanakan pada tanggal 26,28,29 Maret 2018 sesuai dengan jadwal pelaksanaan siklus II yang telah diatur dalam tabel 16 dengan tiga kali pertemuan dan $\mathrm{KD}$ yang berbeda dari siklus I serta indikator yang berbedabeda untuk setiap pertemuannya yaitu pertemuan pertama dan pertemuan kedua, sedangkan pertemuan ketiga kegiatam pembelajaran hanya mengulas materi yang telah dipelajari pada pertemuan pertama dan kedua pada siklus II dan mengerjakan soal evaluasi. Pelaksanaan siklus II melalui beberapa tahap yaitu tahap perencanaan, pelaksanaan, observasi dan refleksi.

Hasil observasi kegiatan mengajar guru siklus II yang dilakukan oleh observer pada peneliti kelas 4 pelajaran matematika saat mengajar menggunakan model pembelajaran discovery learning dapat dilihat pada tabel 4

TABEL 4

HASIL OBSERVASI MENGAJAR GURU SIKLUS II

\begin{tabular}{|l|l|l|l|}
\hline NO & $\begin{array}{l}\text { Indikator } \\
\text { Penilaian }\end{array}$ & $\begin{array}{l}\text { No Item yang } \\
\text { Dilakukan } \\
\text { Guru }\end{array}$ & $\begin{array}{l}\text { Juml } \\
\text { ah }\end{array}$ \\
\hline $\mathbf{1}$ & $\begin{array}{l}\text { Indikator } \\
\text { kegiatan yang } \\
\text { dilakukan oleh } \\
\text { guru }\end{array}$ & $\begin{array}{l}\mathbf{1 , 2 , 3 , 4 , 6 , 7 , 8 , 9 , 1 0 , 1 3 , 1 4 , 1 5 , 1 6 , 1} \\
\mathbf{7 , 1 8 , 1 9 , 2 0 , 2 1 , 2 2}\end{array}$ & $\mathbf{2 1}$ \\
\hline $\mathbf{2}$ & $\begin{array}{l}\text { Indikator } \\
\text { kegiatan } \\
\text { mengajar yang } \\
\text { tidak dilakukan } \\
\text { oleh guru }\end{array}$ & $5,23,24$ & 3 \\
\hline
\end{tabular}

Berdasarkan data hasil belajar matematika siklus II dengan membandingkan KKM matematika yaitu $\geq$ 70, diperoleh hasil bahwa masih ada siswa yang belum mencapai KKM. Berikut disajikan tabel analisis ketuntasan hasil belajar matematika siklus I siswa kelas 4 SD Negeri Cukil o1 Semester II/2017-2018.

TABEL 5

ANALISIS KETUNTASAN HASIL BELAJAR MATEMATIKA SIKLUS II SISWA KELAS 4 SD NEGERI CUKIL 01 SEMESTER II/2017-2018

\begin{tabular}{|l|l|l|l|}
\hline No & \multicolumn{1}{|c|}{ Ketuntasan } & \multicolumn{1}{|c|}{ F } & \multicolumn{1}{c|}{$\%$} \\
\hline 1 & Tuntas & $\mathbf{2 4}$ & $82 \%$ \\
\hline $\mathbf{2}$ & Tidak Tuntas & 5 & $18 \%$ \\
\hline & Rata-rata & 82,5 \\
\hline & Nilai Maksimum & 100 \\
\hline & Nilai Minimum & 40 \\
\hline
\end{tabular}

Berdasarkan tabel 11 terlihat bahwa siswa yang mencapai batas KKM yaitu $\geq 70$ berjumlah 24 siswa dengan persentase $82 \%$ dan yang belum mencapai KKM yaitu $<70$ berjumlah 5 siswa dengan persentase 18\%. Memiliki rata-rata kelas 82,5 dengan nilai minimum 40 dan nilai maksimum 100.

\section{Analisis Komparatif}

Berdasarkan analisis ketuntasan dan data yang diperoleh saat pra siklus maka dapat dilakukan analisis komparatif ketuntasan hasil belajar antar siklus dan pra siklus. Berikut tabel analisis komparatif ketuntasan hasil belajar matematika siswa kelas 4 SD Negeri Cukil 01 Semester II/2017-2018 (tabel 6). 
TABEL 6

ANALISIS KOMPARATIF KETUNTASAN HASIL BELAJAR MATEMATIKA SISWA KELAS 4 SD

NEGERI CUKIL 01 SEMESTER II/2017-2018

\begin{tabular}{|l|l|c|c|c|c|c|c|}
\hline \multirow{2}{*}{ No } & \multirow{2}{*}{$\begin{array}{c}\text { Ketuntas } \\
\text { an }\end{array}$} & & \multicolumn{2}{|c|}{$\begin{array}{c}\text { Pra } \\
\text { Siklus }\end{array}$} & \multicolumn{2}{c|}{ Siklus I } & \multicolumn{2}{c|}{ Siklus II } \\
\cline { 3 - 8 } & & f & \% & F & \% & f & \% \\
\hline 1 & Tuntas & 8 & $27 \%$ & 19 & $65 \%$ & 24 & $82 \%$ \\
\hline 2 & $\begin{array}{l}\text { Tidak } \\
\text { Tuntas }\end{array}$ & 21 & $73 \%$ & 10 & $35 \%$ & 5 & $18 \%$ \\
\hline & Rata-rata & \multicolumn{2}{|c|}{56,06} & \multicolumn{2}{|c|}{65,47} & \multicolumn{2}{c|}{82,5} \\
\hline & $\begin{array}{l}\text { Nilai } \\
\text { Maksimu } \\
\text { m }\end{array}$ & \multicolumn{2}{|c|}{83} & \multicolumn{2}{|c|}{100} & \multicolumn{2}{|c|}{100} \\
\hline & $\begin{array}{l}\text { Nilai } \\
\text { Minimum }\end{array}$ & \multicolumn{2}{|c|}{36} & \multicolumn{2}{|c|}{30} & \multicolumn{2}{|c|}{40} \\
\hline
\end{tabular}

Dari tabel 6 dapat dilihat adanya peningkatan hasil belajar matematika siswa kelas 4 SD Negeri Cukil 01 untuk setiap siklusnya. Untuk lebih jelasnya dapat dilihat dalam grafik berikut ini (gambar 1).

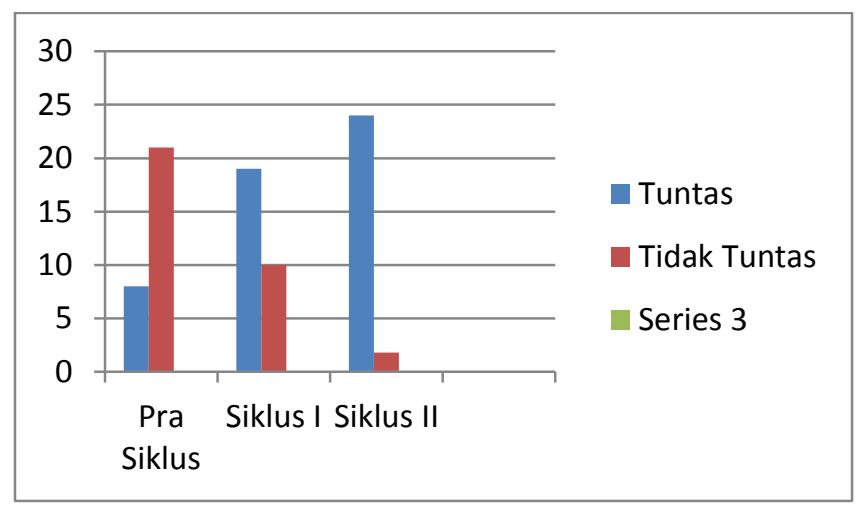

Gambar 6. Grafik Analisis Komparatif Ketuntasan Hasil Belajar Matematika Siswa Kelas 4 SD Negeri Cukil o1 Semester II/2017-2018.

Berdasarkan tabel dan grafik diatas, KKM yang ditentukan $\geq 70$ pada pra siklus menunjukkan bahwa hanya 8 siswa yang tuntas dengan persentase $27 \%$ dan yang tidak tuntas 21 siswa dengan persentase $73 \%$ dengan nilai rata-rata kelas 56,06. Pada siklus I, sudah mengalami peningkatan hasil belajar sebanyak 19 siswa tuntas dengan persentase $65 \%$ dan yang tidak tuntas sebanyak 10 siswa dengan persentase $35 \%$ dengan nilai rata-rata kelas 65,47. Dan pada siklus II, meningkat sebanyak 24 siswa dengan persentase $82 \%$ dan yang tidak tuntas berkurang menjadi 5 siswa dengan persentase $5 \%$ dengan nilai rata-rata 82,5 .

\section{PEMBAHASAN}

Berdasarkan hasiil analisis komparatif, hasil belajar matematika siswa kelas 4 SD Negeri Cukil o1 Kecamatan Tengaran Kabupaten Semarang setelah diterapkan model Discovery Learning menunjukkan peningkatan disetiap siklusnya bahkan hasil yang diperoleh mencapai batas KKM ( $\geq 70$ ). Sebaliknya, asil belajar matematika pra siklus menunjukkan bahwa hasil matematika siswa kelas 4 tergolong rendah karena siswa yang mencapai KKM lebih sedikit daripada yang tidak mencapai KKM.

Hasil belajar matematika siswa kelas 4 pra siklus tergolong rendah, karena yang mencapai batas KKM $\geq$ 70 atau masuk kategori tuntas hanya 8 siswa dengan presentase $27 \%$. Sedangkan siswa yang tidak mencapai batas KKM $<70$ berjumlah 21 siswa dengan persentase $73 \%$, memiliki rata-rata 56,06 dengan nilai maksimal 83 dan nilai minimal 36 . Rendahnya hasil belajar yang diperoleh salah satunya disebabkan oleh model atau metode yang digunakan oleh guru dalam KBM.

Berdasarkan hasil observasi dan wawancara dengan guru kelas 4 diketahui bahwa guru dalam melaksanakan KBM sering menggunakan metode ceramah dan penugasan. Metode ini cenderung berpusat pada guru (teacher centered), siswa hanya menerima penjelasan tentang ide-ide yang ada di dalam buku yang mereka pelajari kemudian mengerjakan latihan-latihan soal. Pembelajaran ini membuat siswa kurang aktif, padahal dalam pembelajaran matematika maupun pembelajaran lainnya guru dituntut menggunakan metode pembelajaran yang sesuai dengan karakteristik siswa yaitu berpusat pada siswa (student centered).

Dengan menerapkan model Discovery Learning diduga dapat meningkatkan hasil belajar siswa. Hal ini didasari karena model ini mengajak siswa untuk menemukan konsepnya sendiri. Melalui kegiatan penemuan, siswa akan cepat memahami materi yang dipelajarinya sebab siswa mengalami langsung bagaimana menemukan konsepnya sendiri dalam rangka menyelesaikan masalah. jika siswa paham dengan materi yang dipelajari maka hasil belajarpun akan meningkat. Hal ini dikarenakan tinggi rendahnya hasil belajar siswa ditentukan oleh tingkat pemahaman siswa terhadap materi yang dipelajari.

Berdasarkan analisis komparatif siklus I dan siklus II membuktikan pernyataan bahwa model Discovery Learning dapat meningkatkan hasil belajar. Hal ini ditunjukkan dengan semakin meningkatnya hasil belajar matematika yang dicapai oleh siswa kelas 4 SD Negeri Cukil 01, bahkan mencapai batas KKM dan mengarah pada pencapaian indikator kinerja yang telah ditetapkan.

Pada siklus I, siswa yang mendapat hasil belajar matematika $\geq 70$ (kategori tuntas) mencapai 19 siswa dengan persentase $65 \%$ dan yang mendapat hasil belajar matematika $<70$ (kategori tidak tuntas) hanya 10 siswa dengan persentase $35 \%$ lebih sedikit dibandingkan pra siklus yang mencapai $73 \%$. Rata-rata yang diperoleh dari hasil belajar matematika siklus I 65,47 dengan nilai maksimum 100 dan nilai minimum 30.

Pada siklus II hasil belajar matematika mengalami peningkatan dibandingkan pada siklus I. Pada siklus II siswa yang tuntas berjumlah 24 siswa dengan 
persentase $82 \%$. Sedangkan siswa yang tidak tuntas menjadi 5 siswa dengan persentase $18 \%$. Dari hasil belajar matematika siklus II diperoleh rata-rata kelas 82,5 dengan nilai maksimum 100 dan nilai minimum 40 .

Siklus II dilaksanakan berdasarkan perbaikanperbaikan dalam menerapkan model Discovery Learning yang telah dilaksanakan pada siklus I. Walaupun pembelajaran sudah terlaksana dengan baik, ternyata masih ada siswa yang masuk dalam kategori tidak tuntas. Kemungkinan siswa tersebut kurang cocok dengan model Discovery Learning. Selain itu peneliti juga melakukan penyelidikan terhadap kelima siswa yang tidak tuntas ditemukan bahwa ada faktor lain yang mempengaruhi ketidak tuntasan hasil belajar matematika yang diperoleh. Secara garis besar, berikut faktor-faktor yang mempengaruhi: (1) kemampuan kognitif siswa yang kurang, (2) minat belajar yang rendah, (3) kondisi kesehatan siswa, (4) tidak fokusnya konsentrasi siswa.

Berdasarkan hasil pembahasan dapat disimpulkan bahwa penerapan model Discovery Learning dapat meningkatkan hasil belajar matematika siswa kelas 4 SD Negeri Cukil o1 Kecamatan Tengaran Kabupaten Semarang semester II tahun pelajaran 2017/2018. Yang dibuktikan adanya peningkatan siswa yang tuntas dari pra siklus yang menghasilkan 8 siswa tuntas dengan persentase $27 \%$, kemudian meningkat menjadi 19 siswa ynag tuntas dengan persentase 65\% pada siklus I, dan meningkat lagi siswa yang tuntas pada siklus II yaitu 24 siswa dengan persentase $82 \%$.

Keberhasilan yang terjadi karena dalam pembelajaran telah menerapkan langkah-langkah pembelajaran model Discovery Learning yang terbagi menjadi 2 tahap yaitu: (1) Tahap persiapan terdiri dari; menentukan tujuan pembelajaran, melakukan identifikasi karakteristik siswa, memilih materi pelajaran, menentukan topik-topik yang harus dipelajari siswa secara induktif, mengembangkan bahan-bahan ajar, mengatur topik pelajaran, melakukan penilaian proses dan hasil belajar. (2) Tahap prosedur terdiri dari; stimulasi / pemberian rangsangan, pernyataan / identifikasi masalah, pengumpulan data, pengolahan data, pembuktian, menarik kesimpulan / generalisasi.

\section{E. SIMPULAN DAN SARAN}

Berdasarkan hasil penelitian pembahasan dapat disimpulkan bahwa metode discovery learning dapat meningkatkan hasil belajar matematika siswa kelas 4 SD Negeri Cukil 01. Hal ini dibuktikan dari meningkatnya jumlah siswa yang tuntas atau telah mencapai $\mathrm{KKM} \geq 70$ yakni: pada pra siklus siwa yang tuntas berjumlah 8 siswa dengan persentase $27 \%$ dan 21 siswa lainnya yang tidak tuntas dengan persentase $73 \%$ memperoleh rata-rata 56,06 dengan nilai maksimum83 dan nilai minimum 36 , pada siklus I siswa yang tuntas mengalami peningkatan yaitu berjumlah 19 siswa dengan persentase 65\% sedangkan yang tidak tuntas berjumlah 10 siswa dengan persentase $35 \%$. Pada siklus II mengalami peningkatan 24 siswa tuntas dengan persentase $82 \%$ sedangkan yang tidak tuntas 5 siswa dengan persentase $18 \%$ dengan rata-rata 82,5 . Nilai maksimum 100 dan nilai minimum 40.

Berdasarkan simpulan, supaya hasil belajar matematika siswa dapat meningkat, maka peneliti memberikan saran sebagai berikut: (1) bagi sekolah, dengan adanya penelitian tindakan kelas ini diharapkan sekolah dapat mempergunakan hasil penelitian sebagai pedoman untuk mengembangkan model pembelajaran agar sekolah bisa menggunakan model discovery learning pada mata pembelajaran matematika khususnya. (2) bagi guru, sebaiknya memperluas pengetahuan tentang macam-macam metode pembelajaran yang dapat meningkatkan hasil belajar khususnya metode discovery learning yang telah terbukti dpaat meningkatkan hasil belajar, (3) bagi siswa, lebih semangat mengasah kemampuan dalam melakukan penemuan supaya dapat menemukan sendiri pengetahuan yang dipelajari tanpa harus menunggu orang lain memberikan informasi.

\section{UCAPAN TERIMA KASIH}

Dengan ini penulis mengucapkan terimakasih kepada Bapak Drs. Wasitohadi, M.Pd, Ibu Theresia Sri Rahayu, S.Pd., M.Pd. guru kelas 4 Ibu Anis Sri Wahyuningsih, S.Pd, dan siswa kelas 4 SD Negeri Cukil o1 yang telah membantu kami sehingga penulis dapat menyelesaikan penelitian ini.

\section{DAFTAR RUJUKAN}

[1]. Alma, B. (2010). Guru Profesional Menguasai Metode dan Terampil Mengajar. Bandung: Penerbit Alfabeta.

[2]. Aunurrahman. (2010). Belajar dan Pembelajaran. Bandung: Alfabeta.

[3]. C, A. (2006). Memahami Konsep Matematika Secara Benar. Jakarta: Departemen Pendidikan Nasional.

[4]. Hamzah. (2007). Model Pembelajaran. Jakarta: Bumi Aksara.

[5]. Hanafiah, C. S. (2009). Konsep Strategi Pembelajaran. Refika Aditama , 77.

[6]. Kebudayaan, K. P. (2014). Modul Pelatihan Implementasi KTSP. Jakarta: Badan pengembangan Sumberdaya Manusia Pendidikan dan Kebudayaan .

[7]. Purwanto. (2010). Prestasi Belajar Anak. Yogyakarta: Pustaka Belajar.

[8]. Sunardi, I. S. (2016). Bahan Ajar PLPG Materi Pedagogik. Jakarta: Kementrian Pendidikan dan Kebudayaan .

[9]. Suryosubroto. (2009). Proses Belajar Mengajar di Sekolah. Jakarta: Rineka Cipta.

[10]. Amanatul. 2016. Peningkatan Berfikir Kritis Matematika melalui Model Kooperatif Tipe Talking Chips Setting Snowball Throwing. E-journal.com, 12-18 
[11].LR Hima. 2016. Penerapan Model PBL. Jurnal Ilmiah Pendidikan Matematika. 4 (2), 111-121

[12]. Widiyahti. 2015. Pengembangan media Pembelajaran Matematika. Jurnal Ilmiah Pendidikan Matematika. 4 (1), 59-70

[13]. Pusat Pembinaan dan Pengembangan Bahasa. 1993. Kamus Besar Bahasa Indonesia (KBBI). Jakarta: Balai Pustaka

[14]. Pusat Pembinaan dan Pengembangan Bahasa. 2005. Kamus Besar Bahasa Indonesia (KBBI). Jakarta: Balai Pustaka.

[15]. Rahmanelli. 2005. Skolar Jurnal Kependidikan. Vol 6. Nomor 2. Padang. UNP.

[16]. Sardiman. 2009. Teori Pembelajaran. Jakarta: Karya Mandiri

[17].Sumanto, Y.D. 2008. Gemar Matematika 6. Jakarta: Pusat Perbukuan Departemen Pendidikan Nasional.

[18]. Hosnan. (2014). Pendekatan Saintifik Dan Kontekstual Dalam Pembelajaran Abad 21. Jakarta: Ghalia Pustaka.

[19]. Kemendikbud. 2013. Materi Pelatihan Guru, Implementasi Kurikulum 2013.Jakarta: Kementerian Pendidikan dan Kebudayaan.

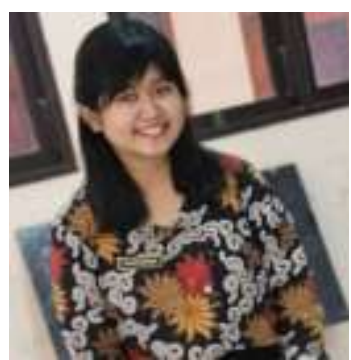

\section{PROFIL PENULIS}

Penulis bernama lengkap "Balad Ikklima". Lahir di Desa Tegalwaton Kecamatan Tengaran Kabupaten Semarang Provinsi Jawa Tengah pada tanggal o2 Juni 1996 dari pasangan Agus Ahmadi dan Sad Emi Suko Asih. Penulis adalah anak pertama dari 3 bersaudara. Pendidikan sekolah dasar dimulai dari SDN Tegalwaton o3pada tahun 2002 2008. Setelah itu melanjutkan pendidikan sekolah menengah atas di SMPN 05 Salatiga pada tahun 2008 - 2011 dan melanjutkan Sekolah Menengah Atas di SMAN 01 Tengaran pada tahun 2011 - 2014. Kemudian penulis melanjutkan studi ke perguruan tinggi di Program Studi Pendidikan Guru Sekolah Dasar FKIP UKSW pada tahun 2014. Kritik, saran, maupun hal-hal yang berkaitan dengan kelanjutan atau pengembangan dari hasil penelitian ini bisa dikirim ke email penulis di: 292014097@student.uksw.edu. 